\title{
Information and Communication Technology Integration in Teacher Education Programmes: Assessment of Science Education Lecturer's Competencies in Rivers State, Nigeria
}

\author{
ETOKEREN, D. Inibehe Sunday ${ }^{1}$, ABOSEDE, Olufunso Olumide ${ }^{2}$ \\ ${ }^{1}$ Department of Science Education, Faculty of Education, Rivers State University, Rivers State Nigeria \\ ${ }^{2}$ Department of Chemistry, Federal University Otueke, Yenegoa, Bayelsa State, Nigeria
}

\begin{abstract}
The relevance of information and communication technology in developing nations of the world like Nigeria cannot be undermined, considering the indispensable role it plays in nations' development and provision of basic facilities for improvement in standards of living of citizens. In this context, science education lecturers need to be fully equipped with basic skills in information and communication technology. This study therefore, is an attempt to assess Science Education Lecturers' competency in information and communication technology in Rivers State. Descriptive survey design was adopted and the sample comprised 85 Science Education Lecturers in Rivers State Tertiary Institutions. The instrument was Competency in Information and Communication Technology Questionnaire validated by two Science Education Lecturers. The instruments' reliability coefficient of 0.76 was determined by test-retest method using Pearson Product Moment Correlation formula. Mean and standard deviation were used for answering research questions while hypotheses were tested using t-test at .05 level of significance. Findings of the study revealed low level of competency of science education lecturers in information and communication technology with regards to use of presentation tools to support on-line instructions, test, assignments, e-mail, face book, internet and cybercafé, analysis of a course work, results computation, course evaluation, word processor for personal and instructional purpose, spreadsheet for personal and instructional purpose, collection and storage of data and decision making. There was no significant difference in male and female lecturers' level of competency in information and communication technology as well as university and college of education science education lecturers in Rivers State. It was recommended among others that Government should ensure adequate training of science education lectures on the use of information and communication technology facilities and also assist them acquire laptops and software packages.
\end{abstract}

KEYWORDS: Competency, Information and Communication Technology, Lecturers, Science Teacher Education Programmes

\section{INTRODUCTION}

Development of any nation of the world depends on advancement in science and technology for the provision of basic human, industrial and other needs for improvement in standards of living for the citizens. This however, to a great extent depends on effective application of information and communication technology facilities and the manufacture of sophisticated digital equipment that can effectively replace the analogue and antiquated ones in line with the demands of this digital age. Based on this premise, and in a conscientious effort to measure with developed Nations of the world, the Nigeria National Economic Empowerment and Development Strategies (NEEDS) established by the Federal Government of Nigeria has been relentless in efforts aimed at ensuring effective teaching of information and communication technology at all levels of education considering its relevance in the process of effective lessons delivery, mostly in developing countries like Nigeria [1]. Appraising this relevance, [2] opined that, effective use of information and communication technology in schools guarantees more and easy access to information and communication experience in this era of globalization. Information and Communication Technology (ICT) is "an equipment or interconnected system of equipment that is used in the automatic acquisition, storage, manipulating, management, control, display, switching and transmission of information [3]. In another perspective, [4] viewed information and communication technology as computer-based tools and techniques for gathering and using information. It encompasses the hardware and software, the network and several other devices (video, audio, photographic camera, etc) that can convert information, images, and sound into common digital form. Information and communication technology include electronic information in processing technologies such as computer and 


\title{
International Journal of Current Science Research and Review
}

\author{
ISSN: 2581-8341
}

Volume 04 Issue 10 October 2021

DOI: 10.47191/ijcsrr/V4-i10-18, Impact Factor: 5.825

IJCSRR@ 2021

www.ijcsrr.org

internet, as well as fixed-line communication networks. There are three basic components of information and communication technology namely: electronic processing using the computer transmission of information, communication equipment, and dissemination of information in multimedia

From the above, proficiencies of lecturers in the use of information and communication technology facilities for lesson delivery and handling of academic materials is imperative in ensuring adequate preparation of the "would-be" teachers for effective lesson delivery at all levels of education. Reasoning in This direction, [5) maintained that implementation of any curriculum is dependent on classroom teacher's intelligent and rational choice of curriculum programmme and materials. The two areas of competencies in the use of information and communication technology facilities are - basic and advanced competencies. Basic competency refers to entry-level skills related to basic computer operation and the use of an array of software that supports and enhance professional productivity. Advanced competency on the other hand, extend the application of basic competencies in teaching, administration, counselling and other professional activities. Science teacher education programmes are types of programmes that are specifically set-up for the training and preparation of teachers in various science subjects which include chemistry, biology, physic and mathematics [6]. They are categorized into Colleges of Education Programmes which award the Nigerian Certificate in Education, and University education programmes which award Bachelor of Education degrees, PostGraduate Diploma in Education (PGDE), Master Degree in Education and Doctor of Philosophy Degree in Education.

This research is rooted on the theoretical framework of Technology Acceptance Model (TAM) propounded [7]. The theory states that the perceived usefulness and perceived ease of use determine an individual's intention to use a system, with the intention to use serving as a mediator of actual system use. The Theoretical basis of technology acceptance model is based on the assumption that when users are presented with a new technology, three major factors influence their decision on how and when they will use it [7]. The first determinant is its perceived usefulness (PU), the second is the perceived ease of use (PEOU) and the third determinant is users' attitude towards usage (ATU). Consequently, perceived usefulness is the degree to which a user believes that using a particular system would enhance its performance. On the other hand, perceived ease-of-use (PEOU) is the degree to which a user believes that using the particular technology would be free rom effort.

Studies on competency in use of information and communication technology in education sector are available. Macqual,and Ichakpa (2014) [8] investigated Federal College of Education Pankshin lecturers' information and communication technology competencies with particular reference to implications for quality teacher education. The study adopted descriptive survey design with the sample of 49 lecturers and Questionnaire for Pankshin Lectures on Information and communication technology Competencies as the instrument. Results of the study showed that majority of the lectures perceived themselves as c competent in both basic and advanced use of information and communication technology. Computer ownership, pre-service training as well as in-service training were significantly related to perceived information and communication technology competencies. Lecturer's competencies did not differ according to gender as well according to basic and advanced usage. Archibong, Ogbiji and AnijaobiIdem ( 2010) [9] studied information and communication technology competence among academic staff in universities in Cross River State, Nigeria. The design was Survey and sample 300 academic staff while information and communication technology competence questionnaire serve as the instrument. Results of the study revealed incompetence in the use of information and communication technology among lecturers in universities in Cross River State. The results further revealed that majority of the academic staff funded their information and communication technology trainings, high number have laptops and access to internet mainly at the public cyber-café. Adedeji [10] investigated the availability and use of information and communication technology in South Western Nigeria Colleges of Education using survey design and 108 students as sample. Results of the study revealed incompetent level of usage of information and communication technology gadgets and non-availability of some information and communication technology equipment.

Egomo, Enyi and Tah [11] investigated the availability and utilization of information and communication technology tools for effective instructional delivery in tertiary institutions in Cross River State, Nigeria. Descriptive survey design was adopted using 300 lecturers as sample. The instrument was Availability and Utilization of Information and Communication Technology Tools for Effective Instructional Delivery Questionnaire. Results of the study showed that, the level of competency in use of information and communication tools among lecturers was very discouraging. Findings of the study further revealed that cyber-cafes, internet facilities and e-mail were very frequently utilized by a good number of lecturers while multimedia, projector, video, cameras, internet facilities and lap tops were not use at all. Gasaymeh [12] examined undergraduates' use of information and communication 


\section{International Journal of Current Science Research and Review}

ISSN: 2581-8341

Volume 04 Issue 10 October 2021

DOI: 10.47191/ijcsrr/V4-i10-18, Impact Factor: 5.825

IJCSRR@ 2021

Www.ijesrr.org

technology. Results of the study showed that students had moderate competencies in the general use of these common technologies, and high competencies in using smart phones. They were users of common digital tools and applications for personal purposes. Gender effect on the use of information and communication technology has also been studied. Nwankwoala [13] for instance, carried out a study titled "an investigation of lecturers' and students use of information and communication technology in Nigerian universities: A panacea for national development" using the sample of 1008 students as sample and information and communication technology usage scale (ICTUS) and national development inventory as instrument. Results revealed that gender of university lecturers did not predict their usage of information and communication technology. Further evidence showed that information and communication technology usage contributed to national development

\subsection{Statement of the Problem}

The National Policy on Teacher Education in Nigeria provides that, as part of undergraduate programs, all student teachers must take courses in information technology and relevant audio visuals and their applications in teaching and learning [14]. To effectively realize this objective, lecturers in our Tertiary Institutions who are charged with the responsibilities of training prospective teachers for all levels of education must ensure production of highly conscientious and efficient classroom teachers for these levels of education. In this regard, it is highly imperative for Science Education Lecturers to attain a considerable level of competency in the application of various information and communication technology packages and programmes for effective lesson delivery and other academic processes. This is an indication that there is a need to ascertain the level of information and communication technology competencies among tertiary institution lecturers mostly science education. Whereas, studies in this regard, seems to have centered around availability and utilization of information and communication technology in Secondary and Tertiary Institutions, competencies of lecturers have not been not been fully explored, as evidenced in limited studies available. Moreover, science education as a discipline has not been considered in any of the studies. This created a problem that study is set to address this problem.

\subsection{Research Questions}

1. What is the level of science education lecturer' competency in information and communication technology in Science in Rivers State?

2. What is the level of male and female lecturers' competency in information and communication technology in Rivers State?

3. What is the level of competency of college of Education and University lecturers' competency in information and communication technology in Rivers State?

\subsection{Hypotheses}

Ho2: There is no significant difference in mean rating of responses between male and female science lecturers on level of competency in information and communication technology in Rivers State.

Ho1: There is no significant difference in mean rating of response of university and college of education lecturers on level of competency in information and communication technology in Rivers State.

\subsection{Significance of the Study}

The outcome of this study will provide government useful information on competency of lectures in information and communication technology in Science Teacher Education Programmes in Rivers State. This will help government to draw appropriate programmes aimed at ensuring competency in information and communication technology. Lecturers stand the chance of using the acquired competency in information and communication technology facilities to easily access educational materials such as lecture notes and handouts apart from textbooks online. This will not only facilitate learning but also make the process of learning easier and easily accessible. Finally, recommendations of this studies will be very useful to curriculum developers by providing useful information which serves as input the curriculum design. Finally, students learning will be enhanced by the effectiveness of application of information and communication technology in the process of lesson delivery.

\section{MATERIAL AND METHODS}

Descriptive Survey design was adopted in this study. The population and sample of this study comprised of 85 science education lecturers representing 47 males and 38 females in the three universities and one college of education (Technical) in Rivers State. 


\section{International Journal of Current Science Research and Review}

ISSN: 2581-8341

Volume 04 Issue 10 October 2021

DOI: 10.47191/ijcsrr/V4-i10-18, Impact Factor: 5.825

The instrument was "Lecturers Competency in Information and Communication Technology Questionnaire" (LCICTQ) rated on a four-point scale, Very competent (VC), Competent (C), Somehow Competent (SC), Not Competent (NC). The instrument was validated by two lecturers in Science Education and one lecturer in Measurement and Evaluation and reliability coefficient established using test-retest method and Pearson Product Moment Correlation to be of 0.76. Research questions were answered using mean and standard deviation while the hypotheses were tested using t-test at 0.05 level of significance. Items with mean rating of 2.5 and above were considered high level while those with mean rating below 2.5 were considered low. Also, null hypotheses were accepted when the calculated value of t, t.cal. was less than table value, t.crit. and rejected when t.cal. is greater than table value t.crit.

\section{RESULTS AND DISCUSSION}

\subsection{Research Question 1}

What is the level of lecturer's competency the in information and communication technology in Rivers State?

Table 1: Mean rating and standard deviation of lecturer's response to level of competence in information and communication technology

\begin{tabular}{|c|c|c|c|c|}
\hline S/no. & Competence & Mean & SD & Decision \\
\hline 1 & $\begin{array}{l}\text { Use of ICT presentation tools to support instructions } \\
\text { e.g. Power Point presentation }\end{array}$ & 2.39 & 0.96 & Low \\
\hline 2 & $\begin{array}{l}\text { Use of ICT to support instruction e.g. email, Facebook, } \\
\text { etc. }\end{array}$ & 1.89 & 0.86 & Low \\
\hline 3 & $\begin{array}{l}\text { Use of ICT internet and cybercafé for sourcing and } \\
\text { sending information }\end{array}$ & 2.31 & 0.93 & Low \\
\hline 4 & $\begin{array}{l}\text { Use of } 1 \mathrm{CT} \text { in course assessment e.g. online test and } \\
\text { assignment }\end{array}$ & 1.87 & 0.75 & Low \\
\hline 5 & $\begin{array}{l}\text { Use of ICT in analysis and computation of results and } \\
\text { evaluation of course }\end{array}$ & 2.35 & 0.89 & Low \\
\hline 6 & $\begin{array}{l}\text { Use of word processor for personal and instructional } \\
\text { purpose. }\end{array}$ & 1.32 & 0.82 & Low \\
\hline 7 & $\begin{array}{l}\text { Use of spreadsheet for personal and instructional } \\
\text { purpose. }\end{array}$ & 1.38 & 0.82 & Low \\
\hline 8 & Use of 1CT for communication e.g. handsets & 2.57 & 0.75 & High \\
\hline 9 & Use of $1 \mathrm{CT}$ for collection and storage of data & 1.26 & 0.97 & Low \\
\hline 10 & Use of $1 \mathrm{CT}$ for decision making & 2.18 & 0.56 & Low \\
\hline
\end{tabular}

From Table 1, lecturers have high level of competence in only one out of ten information and communication technology facilities which is use of phones for communication e.g. hand set 2.57. The level of competence was low in other usage such as use of presentation tools to support instructions e.g. Power Point presentation 2.39, support instruction e.g. email, Facebook 1.89, internet and cybercafé for sourcing and sending information 2.31, assessment process of course e.g. online test! Assignment 1.87, analysis of a course e.g. computation of results and evaluation of course objective 2.35, word processor for personal and instructional purpose 1.32, spreadsheet for personal and instructional purpose 1.38, for collection and storage of data 1.26, for decision making 2.18 .

\subsection{Research Question 2}

What is the level of male and female lecturers' competency in information and communication technology in Rivers State? 


\section{International Journal of Current Science Research and Review}

ISSN: 2581-8341

Volume 04 Issue 10 October 2021

DOI: 10.47191/ijesrr/V4-i10-18, Impact Factor: 5.825

IJCSRR@ 2021

Www.ijcsrr.org

Table 2: Mean rating and standard deviation of male and female lecturers' response on level of competence in information and communication technology

\begin{tabular}{|c|c|c|c|c|c|c|c|}
\hline \multirow[b]{2}{*}{ S/no. } & \multirow[b]{2}{*}{ ICT Competence } & \multicolumn{3}{|c|}{ Male Lecturers } & \multicolumn{3}{|c|}{ Female Lecturers } \\
\hline & & Mean & SD & Decision & Mean & SD & Decision \\
\hline 1 & $\begin{array}{l}\text { Use of ICT presentation tools to support } \\
\text { instructions e.g. Power Point presentation }\end{array}$ & 1.56 & 0.78 & Low & 2.15 & 0.98 & Low \\
\hline 2 & $\begin{array}{l}\text { Use of ICT to support instruction e.g. email, } \\
\text { Facebook, etc. }\end{array}$ & 1.67 & 0.69 & Low & 2.80 & 0.77 & High \\
\hline 3 & $\begin{array}{l}\text { Use of ICT internet and cybercafé for sourcing } \\
\text { and sending information }\end{array}$ & 1.98 & 0.85 & Low & 2.01 & 0.65 & Low \\
\hline 4 & $\begin{array}{l}\text { Use of } 1 \mathrm{CT} \text { in course assessment e.g. online } \\
\text { test and assignment }\end{array}$ & 1.75 & 0.92 & Low & 1.98 & 0.19 & Low \\
\hline 5 & $\begin{array}{l}\text { Use of ICT in analysis and computation of } \\
\text { results and evaluation of course }\end{array}$ & 1.97 & 0.65 & Low & 1.76 & 0.78 & Low \\
\hline 6 & $\begin{array}{l}\text { Use of word processor for personal and } \\
\text { instructional purpose. }\end{array}$ & 1.90 & & Low & 1.89 & 0.97 & Low \\
\hline 7 & $\begin{array}{l}\text { Use of spreadsheet for personal and } \\
\text { instructional purpose. }\end{array}$ & 2.14 & 1.88 & Low & 2.22 & 1.01 & Low \\
\hline 8 & Use of ICT for communication e.g. handsets & 2.68 & 1.97 & High & 2.79 & 1.00 & High \\
\hline 9 & Use of ICT for collection and storage of data & 1.10 & 0.83 & Low & 1.32 & 0.76 & Low \\
\hline \multirow[t]{2}{*}{10} & Use of $1 C T$ for decision making & 2.15 & 0.79 & Low & 2.31 & 0.84 & Low \\
\hline & $\bar{X}$ of $\bar{X}=1.89$ & & & & \multicolumn{3}{|c|}{$\bar{X}$ of $\bar{X}=2.12$} \\
\hline
\end{tabular}

From Table 2, male and female lecturers have low level of competence in the use information and communication technology presentation tools to support instructions e.g. Power Point presentation 1.56 and 2.15, internet and cybercafé for sourcing and sending information 1.98 and 2.01, of 1CT in course assessment e.g. online test Assignment 1.75 and 1.98 , analysis and computation of results and evaluation of course 1.97 and 1.76, word processor for personal and instructional purpose.1.90 and 1.89 , spreadsheet for personal and instructional purpose 2.14 and 2.22, for collection and storage of data1.10 and 1.32, for decision making 2.15 and 2.31. both male and female lecturers have high level of competence in use of information and communication technology for communication e.g handset 2.68 and 2.79

\subsection{Research Question 3}

What is the level of competency of college of Education and University Lecturers' competency in information and communication technology in Rivers State?

Table 3: Mean response and standard deviation of university and college of education lecturers' response to level of competence in information and communication technology.

\begin{tabular}{|c|c|c|c|c|c|c|c|}
\hline \multirow[b]{2}{*}{ S/n. } & \multirow[b]{2}{*}{ Competence } & \multicolumn{3}{|c|}{ University lecturers } & \multicolumn{2}{|c|}{$\begin{array}{l}\text { College } \\
\text { lecturers }\end{array}$} & \multirow{2}{*}{$\begin{array}{l}\text { Education } \\
\text { Decision }\end{array}$} \\
\hline & & Mean & SD & Decision & Mean & SD & \\
\hline 1 & $\begin{array}{l}\text { Use of ICT presentation tools to support } \\
\text { instructions e.g. Power Point presentation }\end{array}$ & 2.43 & 0.78 & Low & 2.56 & 0.99 & High \\
\hline 2 & $\begin{array}{l}\text { Use of ICT to support instruction e.g. email, } \\
\text { Facebook, etc. }\end{array}$ & 1.71 & 1.00 & Low & 1.96 & 0.97 & Low \\
\hline 3 & $\begin{array}{l}\text { Use of ICT internet and cybercafé for sourcing } \\
\text { and sending information }\end{array}$ & 2.12 & 0.76 & Low & 2,43 & 1.01 & Low \\
\hline
\end{tabular}




\section{International Journal of Current Science Research and Review}

ISSN: 2581-8341

Volume 04 Issue 10 October 2021

DOI: 10.47191/ijesrr/V4-i10-18, Impact Factor: 5.825

IJCSRR@ 2021

www.ijcsrr.org

\begin{tabular}{|c|c|c|c|c|c|c|c|}
\hline 4 & $\begin{array}{l}\text { Use of ICT in course assessment e.g. online test } \\
\text { and assignment }\end{array}$ & 1.65 & 0.88 & Low & 1.54 & 0,88 & Low \\
\hline 5 & $\begin{array}{l}\text { Use of ICT in analysis and computation of } \\
\text { results and evaluation of course }\end{array}$ & 2.10 & 0.93 & Low & 2.24 & 0.78 & Low \\
\hline 6 & $\begin{array}{l}\text { Use of word processor for personal and } \\
\text { instructional purpose. }\end{array}$ & 1.08 & 0.72 & Low & 1.97 & 0.96 & Low \\
\hline 7 & $\begin{array}{l}\text { Use of spreadsheet for personal and } \\
\text { instructional purpose. }\end{array}$ & 1.46 & 0,90 & Low & 1.79 & 0.75 & Low \\
\hline 8 & Use of 1CT for communication e.g. handsets & 2.67 & 0.83 & High & 2.54 & 0.86 & High \\
\hline 9 & Use of 1CT for collection and storage of data & 1.18 & 0,69 & Low & 1.09 & 0.97 & Low \\
\hline 10 & Use of ICT for decision making & 2.13 & 0.87 & Low & 2.12 & 0.87 & Low \\
\hline \multicolumn{5}{|c|}{$\bar{X}$ of $\bar{X}=1.85$} & \multicolumn{3}{|c|}{$\bar{X}$ of $\bar{X}=2.01$} \\
\hline
\end{tabular}

Table 3 revealed low level of competency of science education lecturers in information and communication technology in Rivers State with overall mean response of 2.01. Further analysis shows that both university and college of education science education lecturers have low level of competence in use of presentation tools to support instructions e.g. power point presentation 1.71 and 1.96, internet and cybercafé for sourcing and sending information 1.71 and 1.96, course assessment e.g. online test! Assignment 1.65 and 1.54, analysis and computation of results and evaluation of course 2.10 and 2.24, word processor for personal and instructional purpose 1.08 and 1.97, spreadsheet for personal and instructional purpose 1.46 and 1.79 , collection and storage of data1.18 and 1.09, college of education lecturers have high level of competence in use ICT presentation tools to support instructions e.g., Power Point presentation 2.56 while university lecturers had low level of competence.

\section{$3.4 \quad$ Hypothesis 1}

There is no significant difference in mean rating between male and female lecturers' responses on competency information and communication technology in Rivers State.

Table 4: t-test analysis of mean rating of responses of male and female lecturers on competency in information and communication technology.

\begin{tabular}{llllllllll}
\hline Level & $\mathbf{N}$ & $\bar{X}$ & Sd & Df & St.error & t-cal. & t-crit & Sig.level & Decision \\
\hline Male & 57 & 1.89 & 0.2825 & & & & & \\
& & & & 83 & 0.0045 & 1.212 & 1.960 & 0.05 & accepted \\
Female & 25 & 2.12 & 0.2316 & & & & & \\
\hline
\end{tabular}

From Table 4, the calculated value of $\mathrm{t}$, tcal $=1.212$ is less than the table value $\mathrm{t}$-crit. Therefore, the hypothesis which states that there is no significant difference in mean rating between male and female lecturers' responses on competency in information and communication technology in science teacher education in Rivers State is accepted. This means that there is no significant difference between male and female lecturers' competency in information and communication technology in science teacher education in Rivers State.

\subsection{Hypothesis 2}

There is no significant difference in mean rating between university and college of education lecturer's response on competency information and communication technology in Rivers State. 


\section{International Journal of Current Science Research and Review}

ISSN: 2581-8341

Volume 04 Issue 10 October 2021

DOI: 10.47191/ijcsrr/V4-i10-18, Impact Factor: 5.825

IJCSRR@ 2021

www.ijcsrr.org

Table 5: t-test analysis of mean rating of university and college of education lecturers on competency in information and communication technology

\begin{tabular}{|l|l|l|l|l|l|l|l|l|l|}
\hline Institution & $\mathbf{N}$ & $\bar{X}$ & Sd & Df & St. error & t-cal. & t-crit & Sig.level & decision \\
\hline University & 52 & 1.85 & 0.42 & & & & & & \\
\hline & & & & 83 & 0.0039 & 1.415 & 1.960 & 0.05 & accepted \\
\hline College of Education & 33 & 2.01 & 0.34 & & & & & & \\
\hline
\end{tabular}

From Table 5, the calculated value of $\mathrm{t}, \mathrm{t}$-cal $=1.425$ is less than the table value, $\mathrm{t}$-crit. Therefore, the null hypothesis which states that there is no significant difference in mean rating between university and college of education lecturers on competency in information and communication technology in science teacher education in Rivers State is accepted. This means that, there is no significant difference between university and college of education lecturers on competency in information and communication technology in science teacher education in Rivers State.

\section{DISCUSSION OF FINDINGS}

Results in Table 1 revealed low level of competency of lecturers in information and communication technology in science Teacher Education in Rivers State. Science education lecturers recorded low level of competency in the use of internet, computer, cybercafe, overhead projector and seminars, multimedia for class management, e-mails for exchange of academic ideas, scanner for academic works, e-library during teaching and learning process. Results of this study corroborates the findings of [11] and [9] where low and discouraging level of lecturers' competency in use of information and communication tools for instructional delivery in tertiary institutions in Cross River State was found. The results, however does not corroborate that of [7] where majority of the lectures perceived themselves as competent in both basic and advanced use of information and communication technology in federal college of education. Low level of competency of science education lecturers in information and communication technology in this study implies poor implementation of integration of information and communication technology policies in teacher education programmmes in Rivers State. This is counterproductive to realization of the objectives of national policy on teacher education in Nigeria. A lecturer who is incompetent in use of information and communication technology cannot effectively utilized available computers and electronic gadgets to suit the modern innovations in science teaching. Therefore, in most cases, the lecturers are left with no other option than use of paid experts in business centers where security of essential and confidential documents such as question papers and examination scores may not be guaranteed. Consequent, the quality of our science teachers cannot be guaranteed, not minding the relevance of information and communication technology in developing country like Nigeria.

There was no significant difference in level of competency in information and communication technology between male and female science teacher education lecturers in Rivers State (Table 4). The absence of gender related significant difference in competency among science education lecturers is an indication that both male and female lectures lack the requisite skills in the use information and communication packages. This result corroborates the findings of [7] where lecturer's competency in utilization of information and communication technology did not differ according to gender in Federal College of Education.

Results in Table 5 showed that there was no significant difference between university and college of education lecturers' competency in information and communication technology in science teacher education in Rivers State. This implies that the problem of low level of science lecturers' competency in information and communication technology is prevalent in both universities and colleges of education. The overall effect of low level of competency in information and communication technology among university and college of education lectures is a pointer the fact that the quality of graduates with Nigeria Certificate of Education Certificate issued by universities and Post Graduate Diploma in Education Bachelor of Education and Doctor of Philosophy Degrees awarded by Nigerian Universities are questionable

\section{CONCLUSION}

There is low level of competency in information and communication technology among science education lecturers in Rivers State. No significant gender related difference exists in the level of competency as well as university and college of education lecturers 


\section{International Journal of Current Science Research and Review}

ISSN: 2581-8341

Volume 04 Issue 10 October 2021

DOI: 10.47191/ijcsrr/V4-i10-18, Impact Factor: 5.825

IJCSRR@ 2021

Www.ijesrr.org

\section{RECOMMENDATIONS}

Based on the findings of this study, the following recommendations were made.

1 Adequate training on the use of information and communication technology facilities should be given to lectures in tertiary institutions

2. Provision should be made to assist lecturers acquire soft wares that can facilitate mastery of operations on information and communication technology facilities for effective lesson delivery

3. Government and voluntary agencies should assist in provision of information and communication technology facilities to tertiary institutions

\section{REFERENCES}

1. Ogwa, E. Effective technology and vocational education teacher training programmes: A panacea for national transformation. In Proceedings of the 25th annual national conference, organized by NATT. Held in Benue State University, Mark///urdi Nigeria, 2013, pp11-17.

2. Nwobi, A., Ugwoke, N., Nwachukwu, R., Ogbonnaya, A. K. Implementation of information communication technology in teaching and learning process for sustainable development of adults in West Africa Sub Sahara Region. Journal of Education and Practice, 7(22), 2016, pp14-19.

3. Federal Republic of Nigeria. (FRN). National policy on education. Federal Republic of Nigeria., 2014.

4. Kepeghom O.M. Availability and impact of ICT on teaching and learning ability on students in Federal College of Education (Technical) Omoku-Nigeria. International Journal of Emerging Technology and Advanced Engineering, 4(7), 2014, pp $806-812$.

5. Amesi, J., and Yellow, I. T. Availability and utilization of information and communication technology gadgets in faculties of education in Rivers State Universities, Nigeria. International Journal of Education and Evaluation.; 4(4), 2018, pp 2636 .

6. Abdulwahab, S. and Rasheed, H. S.. Refocussing technical teachers' education programmes towards youth empowerment. Journal of Humanities and Social Science.; 19 (10), 2014, pp 69-73.

7. Davis, F. D.. Perceived usefulness, perceived ease of use and user acceptance of information technology. MIS Quarterly.: 13(3), pp318- 346

8. Macqual, S. M. and Ichakpa, V. An investigation of federal college of education Pankshin lecturer's information and communication technology (ICT) competency: Implications for quality teacher education. International Journal of Research in Science, Technology and Mathematica education.; 2(1), 2014, pp 87-96.

9. Archibong, I. A., Ogbiji, J. E, and Anijaobi-Idem F.. Information and communication technology competence among academic staff in universities in Cross Rivers State, Nigeria, Computer and Information Science.; 3(4), 2010, pp109-115.

10. Adedeji, T.. Availability and use of information and communication technology in South Western Nigeria Colleges of Education. African Research Review International Multidisciplinary Journal, Ethiopia.; 5(5) 8, 2011, pp315-331.

11. Egomo, J. E., Enyi, B. I. and Tah, M.M. Availability and utilization of ICT tools for effective instructional delivery in tertiary institutions in Cross River State, Nigeria. Global Advanced Research Journal of Educational Research and Review.; 1(8), 2012, pp 190-195.

12. Gasaymeh, A.. A study of undergraduate students' use of information and communication technology (ICT) and factors affecting their use: A developing country perspective. Eurasia Journal of Mathematics Science and Technology Education. 14(5), 2018, pp 1731-1746.

13. Nwankwoala, C. A.. An investigation of lecturers' and students use of information and communication technology in Nigerian universities: A panacea for national development”. In Proceedings of International conference on Education. University of Port Harcourt, 2015

14. Federal Ministry of Education, (FME). National policy on education. Lagos: NDRC, 2014.

Cite this Article: ETOKEREN, D. Inibehe Sunday, ABOSEDE, Olufunso Olumide (2021). Information and Communication Technology Integration in Teacher Education Programmes: Assessment of Science Education Lecturer's Competencies in Rivers State, Nigeria. International Journal of Current Science Research and Review, 4(10), 1362-1369 